\title{
THE PREVALENCE OF DEPRESSION AND ANXIETY AND THEIR LIFESTYLE DETERMINANTS IN A LARGE SAMPLE OF IRANIAN ADULTS: RESULTS FROM A POPULATION BASED CROSS-SECTIONAL STUDY
}

Zeinab Alizadeh ${ }^{1,2}$, Awat Feizi ${ }^{2,3}$, Mehri Rejali $^{2}$, Hamid Afshar $^{3}$, Ammar Hassanzadeh Keshteli $^{4}$, Mahbubeh Abdollahi ${ }^{5}$, Peyman Adibi ${ }^{6}$ ${ }^{1} \mathrm{PhD}$ Candidate in Epidemiology; Student Research Committee, Faculty of Public Health Branch, Iran University of Medical Sciences; Tehran; Iran ${ }^{2}$ Department of Biostatistics and Epidemiology, School of Health, Isfahan University of Medical Sciences, Isfahan, Iran. ${ }^{3}$ Psychosomatic Research Center, Isfahan University of Medical Sciences, Isfahan, Iran

${ }^{4}$ Department of Medicine, University of Alberta, Edmonton, Alberta, Canada.

${ }^{5}$ Torbat Heydariyeh University of Medical Sciences, Torbat Heydariyeh, Iran.

${ }^{6}$ Department of Internal Medicine, School of Medicine and Integrative Functional Gastrointestinal Disorders Research Center, Isfahan University of Medical Sciences, Isfahan, Iran.

\section{PREVALENCIJA DEPRESIJE I ANIKSIOZNOSTI I NJIHOVIH DETERMINANTI ŽIVOTA U VELIKOM UZORIKU IRANACA: REZULTATI STUDIJE PRESEKA}

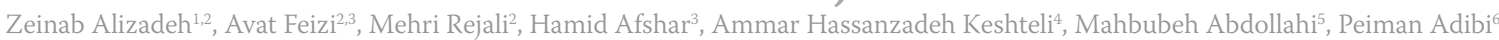
${ }^{1}$ Odsek za javno zdravlje, Škola zdravlja, Univerzitet medicinskih nauka Torbat Heidariieh, Torbat Heidariieh, Iran

${ }^{2}$ Odsek za biostatistiku i epidemiologiju, Škola zdravlja, Univerzitet medicinskih nauka u Isfahanu, Isfahan, Iran ${ }^{3}$ Centar za psihosomatska istraživanja, Univerzitet medicinskih nauka u Isfahanu, Isfahan, Iran

${ }^{4}$ Odsek za medicinu, Univerzitet Alberta, Edmonton, Alberta, Kanada

Torbat Heidariieh Univerzitet medicinskih nauka, Torbat Heidariieh, Iran

${ }^{6}$ Katedra za internu medicinu, Medicinski fakultet i integrativni funkcionalni centar za istraživanje gastroenterologije, Isfahan Univerzitet medicinskih nauka, Isfahan, Iran

\section{ABSTRACT}

Association of lifestyle-related factors and mental health has been less studied in Middle Eastern countries. This study aimed to examine the prevalence of two common mental health problems, i.e., depression and anxiety, and their lifestyle determinants in a large sample of Iranian population.

This study was conducted within the framework of SEPAHAN population based cross-sectional study ( $N=4763$ (. The General Practice Physical Activity Questionnaire (GPPAQ) was used to assess physical activity and the Iranian-validated version of Hospital Anxiety and Depression Scale (HADS) was applied to screen for anxiety and depression. Logistic regression was used as the main statistical method for data analysis by SPSS version 16.0. A P-value $<0.05$ was considered to be statistically significant.

The risk of anxiety and depression was 2.5 (OR=2.56,95\% CI: 1.97-3.33) and 2.21(1.83-2.67) times higher in women than men, respectively. With every one-year increase in the age, the risk of anxiety decreased by 2\% (OR=0.98,95\% CI:0.970.99). Individuals with higher education had $56 \%$ lower risk of anxiety (OR=0.44,95\% CI: 0.36-0.55) and 46\% depression $(\mathrm{OR}=0.54,95 \%$ CI: 0.46-0.64) than the undergraduate group, and the risk of depression in the inactive (less than one hour of activity per week) group was 27\% higher than the active group (OR=1.27,95\% CI: 1.06-1.51). The risk of anxiety in the non-smoker group was $65 \%(O R=0.35,95 \% \mathrm{CI}: 0.20-0.59)$ and depression was $64 \%$ lower than among smokers (OR=0.34,95\% CI:0 .22-0.53). In the ex-smoker group, the risk of anxiety was 60\% (OR=0.40,95\% CI:0.19-0.85) and depression was 59\% lower than for the smoker group $(\mathrm{OR}=0.41,95 \%$ CI: 0.24-0.73).

\section{SAŽETAK}

Udruženje faktora vezanih za način života $i$ mentalnog zdravlja u zemljama Bliskog istoka je dosada malo istraživano. Ova studija imala je za cilj da se ispita prevalencija dva česta mentalna zdravstvena problema, tj. depresiju $i$ anksioznost, $i$ njihove determinante u velikom uzorku iranske populacije. Studija je sprovedena u okviru SEPAHAN-a studije preseka (n = 4763). Upitnik opšte fizičke aktivnosti (GPPAQ) je korišćen za procenu fizičke aktivnosti $i$ iranska validirana verzija skale bolničke anksioznosti i depresije (HADS) primenjena je za praćenje anksioznosti i depresije u populaciji. Logistička regresija je korišćena kao glavni statistički metod za podatke u programu SPSS verzije 16.0. Statistički značajnom je smatrana $p$ vrednost $<0,05$.

Rizik od anksioznosti $i$ depresije bio je 2,5 (OR = 2.56,95\%) CI: 1,97-3,33) i 2,21 (1,83-2,67) puta više nego kod žena muškaraca. Sa svakim jednogodišnjim povećanjem starosti, rizik od anksioznosti se smanjio za $2 \%(O R=0,98,95 \%$ CI: 0,97-0,99). Pojedinci sa visokim obrazovanjem imali su $56 \%$ manji rizik anksioznosti (OR $=0,44,95 \%$ CI: 0,36-0,55) $i$ $46 \%$ depresije $(O R=0,54,95 \%$ CI: 0,46-0,64) nego grupa studenata, $i$ rizik od depresije kod neaktivnih (manje od jednog sata nedeljno) ispitanika je bila $27 \%$ veća od aktivne grupe $(O R=1,2795 \%$ CI: 1,06-1,51). Postoji rizik od anksioznosti u grupi nepušača i bila je 65\% (OR = 0,35 95\% CI: 0,200,59) i depresije, koja je bila 64\% niža nego kod pušača (OR= 0,34 95\%) CI: 0,22-0,53). U grupi bivših pušača, rizik od anksioznosti je bio 60\% (OR =0,40 95\% CI: 0,19-0,85) $i$ depresija je bila zastupljena 59\% manje nego u grupi pušača (OR =0,41 95\% CI: 0,24-0,73). Rezultati ove studije pokazali

\section{sciendo}

UDK: 616.89-008.454-036.22(55) 616.89-008.441-036.22(55)

Ser J Exp Clin Res 2020; 21 (2): 163-170 DOI: 10.2478/SJECR-2018-0079
Corresponding author: Awat Feizi

Psychosomatic Research Center Isfahan University of Medical Sciences, Isfahan, Iran Department of Biostatistics and Epidemiology Tel: +98 3137923250; Fax: +98 3136682509 E-mail address: awat_feiz@hlth.mui.ac.ir 
This current study's results demonstrated significant associations between unhealthy lifestyle factors and increased risk of anxiety and depression. Hence, special attention must be paid to preventive intervention programmes aiming to enhance healthy lifestyle among at-risk populations.

Keywords: Anxiety, Depression, Life Style, Prevalence su značajne povezanosti izmedu nezdravih faktora načina života i povećanog rizika od anksioznosti i depresije. Dakle, mora se posvetiti posebna pažnja preventivnim programima sa ciljem poboljšanja zdravog načina života među rizičnim populacijama.

Ključne reči: anksioznost, depresija, životni stil, prevalencija

\section{INTRODUCTION}

Mental health is increasingly being considered as one of the main components of public health in society. Mental health problems are common and their prevalence has increased in many countries around the world $(1,2)$. About half of American and $40 \%$ of European populations met the criteria for psychiatric disorders throughout their lives (3, 4). The prevalence of mental health problems in Iran has been reported to range from $10 \%$ to $20 \%(5,6)$. Depression and anxiety are the most common chronic mental health problems among the general population, which negatively affects the quality of life, performance and productivity of individuals as well as society. As a result, these illnesses have been considered to be a public health priority. (7-9).

Mental health is not only influenced by personality traits, living conditions and important life event stressors, but much evidence also suggests that the routine behaviours in the framework of an individual's life style can also have an effect (10). Prospective studies revealed a bidirectional association between mental health and lifestyle factors, in which healthy lifestyle has a positive impact on enhancing mental health, including reducing depression and anxiety symptoms. Better mental health was associated with greater physical activity, normal body mass index, and non-smoking $(10,11,12)$. The association of different lifestyle dimensions including physical activity (13), smoking (14), body mass index (15), and diet (16) with various physical illnesses such as cancer, heart disease and stroke was also shown (10). The relationship between lifestyle and mental health has been shown in various studies. People with depressive symptoms have been found to have an unhealthier lifestyle than people without depressive symptoms. For example, anxiety and depression were significantly lower in both genders among those who were physically inactive, had an unhealthy diet and were smokers (17-19).

People with mental health problems require not only clinical treatments but also behavioural interventions for promoting lifestyle factors in order to enhance mental health. In fact, the need for health promotion, prevention programmes and treatment of mental disorders is certainly the primary health challenge of the 21st century.

If a population-based study shows that lifestyle factors are associated with anxiety and depression, general edu- cation in the field of lifestyle can be effective in reducing these disorders and their outcomes.

Most of the previous studies in this field to date have focused on one aspect of lifestyle and primarily on physical illness. AdditionallyIn addition, these studies have been conducted in specific instead of general populations. The evaluation of the simultaneous impacts of multiple lifestyle factors on mental health problems provides more reliable conclusions. This study is the first large population-based study among Iranian adults aimed at investigating the association of multiple lifestyle and demographic factors with anxiety and depression.

\section{METHODS}

\section{Study design and participants}

The current cross-sectional study was conducted in the framework of the Study on the Epidemiology of Psychological, Alimentary Health and Nutrition (SEPAHAN), describing the epidemiological aspects of functional gastrointestinal disorders and their association with lifestyle and psychological factors in 2010. Details about SEPAHAN have already been published (20). The studied population was selected from among 4 million people living in 20 counties across the Isfahan Province, Iran. Multistage random cluster sampling was performed by geographical regions to select participants from each region. The participants were selected from healthy people who lived in Isfahan Province. The questionnaires were issued to the participants in their home and workplace, and the participants answered the questionnaires in their free time. All data were collected anonymously and confidentially. Participation in this study was completely optional. To increase the accuracy of data and response rate, data were collected in two separate waves. The first wave was implemented in April 2010, and participants returned completed questionnaires within 7 days, and the second wave was implemented in mid-May 2010. In the first wave, 8,691 questionnaires out of 10,087 distributed questionnaires were returned (response rate: $86.16 \%$ ). Data regarding gastrointestinal and mental health disorders were gathered in the second phase (response rate: 64.6\%). In 
the end, 4,763 questionnaires obtained in the second wave were matched with their equivalent questionnaires in the first wave. In this study, we used the data from 4,763 adults. The protocol of study was approved by the ethics committee of Isfahan University of Medical Sciences (IUMS) and was clarified for all the participants before participating in the study. Written informed consent was obtained from all participants.

\section{Study instruments and variables assessment}

The physical activity of study participants was assessed using the General Practice Physical Activity Questionnaire (GPAQ). This questionnaire is a simple validated screening tool for ranking the physical activity of adults by focusing on current general activities (21). Participants were classified into 4 categories: active ( $>3 \mathrm{~h} /$ week), moderately active (1-3 h/week), moderately inactive $(<1 \mathrm{~h} /$ week), and inactive (no physical activity), based on the type and intensity of their physical activities in work hours and during the weekends. Finally, participants were categorized into two major groups: active and inactive. Participants were classified as active if they engaged in physical activity for more than one hour per week and inactive if they engaged in less than one hour of physical activity per week. The validity of the GPAQ for the assessment of habitual physical activity levels has been shown in earlier studies (21).

In SEPAHAN, information about mental health disorders, including depression, anxiety and psychological distress, was obtained from the validated Iranian version of Hospital Anxiety and Depression Scale (HADS). HADS includes two discrete parts assessing the severity of anxiety and depression. There are 7 questions with a fourpoint rating scale in each part. Higher scores demonstrate a greater severity of anxiety or depression. The possible scores ranged from 0 to 21 for both disorders. According to the values suggested by earlier studies assessing the validity and reliability of HADS in Iranians, scores of 8 or higher in either part were considered to indicate the presence of anxiety or depression, while scores of 7 or less were considered normal (22).

\section{Assessment of other variables}

Demographic data were collected regarding age (years), sex (male, female), marital status (single, married), educational level (less than diploma, diploma based on 12 years of formal education, university graduation). Participants who had a diploma or less than a diploma were considered to be undergraduates and those who had university educational levels were considered to be university graduates. Health data regarding smoking (current smoker, ex-smoker, non-smoker), weight (kilograms) and height (centimetres) were obtained using a self-reported questionnaire. Body mass index (BMI) was calculated as weight in kilograms divided by the square of height in metre. In our validation study of 200 participants from the same popu- lation, we found that the correlation coefficient between self-reported and the measured weight and height were $0.95(\mathrm{P}<0.001)$ and $0.83(\mathrm{P}<0.001)$, respectively. The correlation coefficient for the computed BMI from self-reported values and from the measured values was $0.70(\mathrm{P}<0.001)$. Participants were classified into three categories based on their BMI: normal weight (18.5-24.9 $\left.\mathrm{kg} / \mathrm{m}^{2}\right)$, overweight $\left(25-29.9 \mathrm{~kg} / \mathrm{m}^{2}\right.$ ) or obese (more than $29.9 .0 \mathrm{~kg} / \mathrm{m}^{2}$ ).

\section{Statistical analyses}

Continuous and categorical data were presented as the mean \pm SD and frequency (percentage). Continuous data were compared between depressed and anxious and non-affected participants using independent samples t-test and categorical data using the chi-square test. Multiple logistic regression analysis was used for evaluating the association between demographic and lifestyle determinants of anxiety and depression, and the associations were depicted as odds ratio (OR) and 95\% confidence interval (95\% CI for OR). All statistical analysis was conducted using SPSS version 16 (SPSS Inc, Chicago, IL, USA).

\section{RESULTS}

Table 1 presents the basic characteristics of study participants and the prevalence of anxiety and depression in categories of demographic and life style variables. Among the participant samples, 2106 (44.2\%) were male and 2657 $(55.8 \%)$ were female. The mean age was $36 \pm 8.09$ years and the mean BMI was $25 \pm 4.64$.

The results showed that the prevalence of depression and anxiety was $28.8 \%$ and $14 \%$ in the total population, respectively. The prevalence of both anxiety and depression disorders in women was significantly higher than men ( $P$ $=0.001)$. Age was significantly associated with anxiety $(\mathrm{P}=$ 0.02 ), in which the prevalence of anxiety was higher among younger than the older people (older than 50) (14\% vs. $7 \%$ ). Findings also showed that the prevalence of depression was significantly higher in single people $(32.2 \%)$ than the married people $(27.9 \%)$. ( $p=0.01)$. Both anxiety and depression were less prevalent in those people with a higher level of education $(\mathrm{p}=0.001)$.

The prevalence of anxiety in physically inactive people was significantly higher than among physically active people (15\% vs. $11 \%)$; similar results were also observed regarding and the depression (31\% vs. 23\%) (for both, $\mathrm{P}$ $=0.001)$.

The study of smoking status in the total population showed that only $3.6 \%$ were current smokers, $4.7 \%$ were ex-smokers and the remaining population never smoked; among smokers $18.4 \%$ were anxious compared to $13.6 \%$ of those who had never smoked and $12.0 \%$ of ex-smokers who were suffering from anxiety. However, these differences were not statistically significant. Similar results were found regarding the prevalence of depression 
Table 1. Prevalence of depression and anxiety in categories of demographic and lifestyle variables.

\begin{tabular}{|c|c|c|c|c|c|}
\hline & $\begin{array}{l}\text { Total sample } \\
\text { Frequency }(\%)\end{array}$ & $\begin{array}{l}\text { Prevalence (\%) } \\
\text { of anxiety }\end{array}$ & p_value & $\begin{array}{l}\text { Prevalence }(\%) \\
\text { of depression }\end{array}$ & p_value \\
\hline $\begin{array}{l}\text { Male } \\
\text { Female }\end{array}$ & $\begin{array}{l}2106(44.2) \\
2657(55.8)\end{array}$ & $\begin{array}{l}10.0 \\
17.2\end{array}$ & 0.001 & $\begin{array}{l}22.2 \\
33.9\end{array}$ & 0.001 \\
\hline $\begin{array}{c}\text { Age (Yrs) } \\
34-19 \\
50-35 \\
>50\end{array}$ & $\begin{array}{l}1782(43.9) \\
2085(51.4) \\
191(4.7)\end{array}$ & $\begin{array}{c}14.6 \\
14.1 \\
7.3\end{array}$ & 0.021 & $\begin{array}{l}27.8 \\
29.8 \\
28.8\end{array}$ & 0.387 \\
\hline $\begin{array}{l}\text { Single } \\
\text { Married }\end{array}$ & $\begin{array}{l}3776(81.2) \\
874(18.8)\end{array}$ & $\begin{array}{l}14.1 \\
13.5\end{array}$ & .6290 & $\begin{array}{l}27.9 \\
32.2\end{array}$ & .0120 \\
\hline $\begin{array}{c}\text { Undergraduate (Diploma and less than Diploma) } \\
\text { Graduate (University) }\end{array}$ & $\begin{array}{l}1986(42.8) \\
2650(57.2)\end{array}$ & $\begin{array}{l}17.9 \\
11.1\end{array}$ & 0.001 & $\begin{array}{l}33.6 \\
24.9\end{array}$ & 0.001 \\
\hline $\begin{array}{c}\text { Physically inactive (More than one hour per week) } \\
\text { Physically active } \\
\text { (Less than one hour per week) }\end{array}$ & $\begin{array}{l}2855(65.2) \\
1522(34.8)\end{array}$ & $\begin{array}{l}15.1 \\
11.2\end{array}$ & 0.001 & $\begin{array}{l}31.4 \\
23.3\end{array}$ & 0.001 \\
\hline $\begin{array}{l}\text { non-smoker } \\
\text { ex-smoker } \\
\text { smoker }\end{array}$ & $\begin{array}{c}3856(91.7) \\
196(4.7) \\
153(3.6)\end{array}$ & $\begin{array}{l}13.6 \\
12.0 \\
18.4\end{array}$ & .2010 & $\begin{array}{l}27.6 \\
27.2 \\
40.1\end{array}$ & .0040 \\
\hline $\begin{array}{c}\text { Normal-weight }\left(<25 \mathrm{Kg} / \mathrm{m}^{2}\right) \\
\text { Overweight }(25-29.9) \\
\text { Obese }(>30)\end{array}$ & $\begin{array}{c}228(5.0) \\
2199(48.2) \\
2133(46.8)\end{array}$ & $\begin{array}{l}16.8 \\
13.0 \\
14.4\end{array}$ & .1740 & $\begin{array}{l}28.2 \\
27.8 \\
32.4\end{array}$ & 0.320 \\
\hline
\end{tabular}

P-values resulted from Chi-square test.

in BMI categories (32.4\% among smokers, $27.8 \%$ among those who never smoked and $28.2 \%$ among ex-smokers) $(\mathrm{p}=0.32)$. (Table 1$)$.

To investigate the multivariable association of demographic and lifestyle variables with anxiety and depression, two logistic regression models were separately fitted (Table 2 ). The results of the logistic regression analyses showed that gender, age, education and smoking were significant determinants of suffering from anxiety and gender, education, physical activity and smoking were significant predictors of being depressed.

The risk of anxiety in women was 2.56 times higher than men $(\mathrm{OR}=2.56 ; \mathrm{P}<0.0001)$. Women were also more than twice as likely to be affected by depression than men $(\mathrm{OR}=2.2 ; \mathrm{P}<0.0001)$. Older age was inversely associated with a risk of anxiety; with a one-year increase in age, the risk of anxiety decreased by approximately $2 \%(\mathrm{OR}=0.98$; $\mathrm{P}=0.02)$, but depression was not significantly associated with age $(\mathrm{P}=0.35)$.

Level of education was significantly associated with anxiety and depression disorders. Among those with a higher level of education, the risk of anxiety was $56 \%$ lower than among less educated people $(\mathrm{OR}=0.44 ; \mathrm{P}<0.0001)$. The odds of being affected by depression among people with a higher level of education was $46 \%$ less than people with a lower educational attainment $(\mathrm{OR}=0.54 ; \mathrm{P}<0.0001)$.

The results of the regression logistic analysis showed no significant association between anxiety and physical activity, while the risk of depression was significantly higher among inactive people $(\mathrm{OR}=1.27 ; \mathrm{P}=0.01)$. In our multivariable logistic regression analyses we observed a significant association between a smoking habit and depression

Table 2. The results of logistic regression analysis for the association demographic and lifestyle determinants of anxiety and depression

\begin{tabular}{|c|c|c|c|c|}
\hline & \multicolumn{2}{|c|}{ Anxiety } & \multicolumn{2}{|c|}{ Depression } \\
\hline & OR $(95 \% \mathrm{CI})$ & p_value & OR $(95 \% \mathrm{CI})$ & p_value \\
\hline Female & $2.56(1.97-3.33)$ & $<0.0001$ & $2.21(1.83-2.67)$ & $<0.0001$ \\
\hline Male (Reference) & 1 & & 1 & \\
\hline Age & $0.98(0.97-0.99)$ & .020 & $1.01-(0.99-1.02)$ & .3540 \\
\hline Single (Reference) & 1 & & 1 & \\
\hline Married & $0.86(0.65-1.15)$ & .310 & $1.22(0.98-1.51)$ & .0740 \\
\hline Undergraduate (Reference) & 1 & & 1 & \\
\hline graduate & $0.44(0.36-0.55)$ & $<0.0001$ & $0.54(0.46-0.64)$ & $<0.0001$ \\
\hline Physically inactive & $1.18(0.93-1.50)$ & .170 & $1.27(1.06-1.51)$ & .0090 \\
\hline Physically active (Reference) & 1 & & 1 & \\
\hline non-smoker & $0.35(0.20-0.59)$ & & $0.34(0.22-0.53)$ & \\
\hline ex-smoker & $0.40(0.19-0.85)$ & $<0.0001$ & $0.41(0.24-0.73)$ & $<0.0001$ \\
\hline smoker (Reference) & 1 & & 1 & \\
\hline BMI & $0.99(0.97-1.02)$ & .810 & $0.99(0.97-1.01-)$ & .430 \\
\hline
\end{tabular}


and anxiety. The risk of anxiety $(\mathrm{OR}=0.35 ; \mathrm{P}<0.001)$ and depression $(\mathrm{OR}=0.34 ; \mathrm{P}<0.001)$ was lower among people who had never smoked than among participants who were current smokers; also, the risk of experiencing both disorders was lower among ex-smoker than smokers.

\section{DISCUSSION}

The current study was conducted with a large sample of Iranian adults to investigate the association between lifestyle and demographic variables with two common mental health problems, i.e., depression and anxiety, in Iran (23) and as well as in the world $(9,24)$.

In this study, the prevalence of depression and anxiety was found to be $28.8 \%$ and $14 \%$ among the total population, respectively. Among the studied variables, female sex, younger age, lower education level, and a smoking habit were significantly associated with suffering from anxiety. Additionally, female sex, lower education level, less physical activity, and a smoking habit were significantly related to an increased risk of depression.

These findings show that the prevalence of depression and anxiety among the population of Iranian adults was higher compared with the reported rates in other studies in world. The observed variations may be attributed to the socio-demographic background of the studied population, to the differences in methodology and tools for screening, or to classification based on various cut of values and misclassification.

The results of this study showed a higher risk of anxiety and depression in women, which was similar to the results of previous studies $(5,9,25)$. Also in line with the results of previous studies, our study showed a positive and significant relationship between a lower education level and an increased risk of anxiety and depression $(8,26)$. Men and women showed differences in disease presentation and course. In addition to a higher prevalence of mental disorders that meet the full diagnostic criteria, subclinical anxiety and depression symptoms are also more common in women. Understanding the differentiated biological and socio-cultural backgrounds of men and women in their experiences of affective disorders such as mental health problems is likely to be a useful perspective into the mechanisms of these illnesses.

Our study showed that as age increased, the level of anxiety decreased, but there was no significant association between age and depression. Several previous studies also showed a higher prevalence of anxiety in younger age groups $(9,27)$. The findings of the current study are consistent with the findings of community-based epidemiologic surveys, showing an age-related decline in the prevalence of current anxiety disorders; although in some studies, the prevalence of psychological problems increased with age $(5,23)$, and some studies did not show any significant difference (25). Some people have challenged these findings, arguing that epidemiologic surveys may underestimate the prevalence of mental health disorders in older persons due to the reluctance on the part of older people to acknowledge emotional and psychological symptoms, reduced sensitivity of screening survey instruments for older persons, as well as recall bias (28).

The results of previous studies showed a lower prevalence of depression and anxiety among married participants and indicated a better mental health status than among single participants $(10)$; $(29,30)$. However, in the current study, marital status did not show any significant relationship with any of the mental health disorders. This inconsistency likely reflects a variation across studies in several key methodological features, including that the majority of studies of marital disruption exclude the remarried. This exclusion may exaggerate the effect of marital disruption on mental health, especially among women. Additionally, most previous studies have used depression symptom scales rather than standardized diagnostic instruments and the degree of control for history of prior psychopathology varies across studies (31).

In the present study, there was no significant association between BMI and anxiety and depression. By contrast, data from 46,704 participants in a study in Australia revealed a nonlinear relationship between BMI and mental health, wherein obese women were shown to have a higher odds of experiencing mental illness (32). Other studies also showed an increased risk of mental disorders among obese people $(10,33)$. There is a question as to the potential effect of the severity of obesity. There was evidence that depression increases with the severity of obesity $(33,34)$. Another important question that can be posed is whether or not this relationship is causal. Previous studies have shown that depression is a predictor of obesity $(35,36)$, although these findings are shown only for women, and not men (37). The results of a meta-analysis with the aim of determining the relationship between obesity and depression on prospective studies showed that depression predicts obesity and the risk of obesity among depressed people was higher than among non-depressed subjects (38). There is growing evidence that depressive and anxiety disorders share common health problems with obesity such as cardiovascular disease and type II diabetes, which increases the risk of early death. These health problems could partly be explained by an unhealthy lifestyle, which is found to be more common among depressed, anxious and obese people (39).

Physical activity is an important well-known factor, especially in relation to depression. People who are physically inactive are at an increased risk of developing depression, while those who are physically active have are more protected from developing depression. In line with our findings, an inverse association between physical activity and depression has been reported in earlier studies. However, inconsistent with previous studies, we did not find an association between anxiety and physical activity. There is strong evidence from animal studies that exercise and regular activity positively impacts the pathophysiological processes of anxiety. 
Numerous studies and meta-analyses showed an inverse association between exercise and anxiety in clinical settings. Similar to the complex nature of anxiety disorders, no single mechanism sufficiently accounts for the anxiolytic nature of exercise. Physical activity positively impacts a number of biological, as well as psychological mechanisms (40). Exercise is known to be an effective therapeutic strategy for depression and anxiety $(41,42)$.

In the present study, a higher risk for depression and anxiety was shown among smokers compared to nonsmokers and ex-smokers. The results of a meta-analysis of longitudinal studies (2016) revealed a bidirectional relationship between smoking and the occurrence of mental disorders. The bidirectional association between smoking and depression or anxiety may be explained with occasional smoking initially used to alleviate symptoms, but in fact exacerbating symptoms over time. (43). Several hypotheses have been proposed to explain the high rate of smoking among people with depression and anxiety. The theory of self-medication claims that people smoke to reduce symptoms of depression and anxiety, and thus suggests that anxiety and depression may lead to smoking $(44,45)$. Alternatively, it has been suggested that smoking may lead to depression or anxiety through its effect on neuro-circuitry, which increases susceptibility to environmental stressors. Animal models provide evidence that prolonged nicotine exposure deregulates the hypothalamic-pituitary-adrenal system, resulting in the hyper-secretion of cortisol and alterations in the activity of the associated monoamine neurotransmitter system, whose function is to regulate reactions to stressors, an effect that appears to normalize after nicotine withdrawal (37).

This study has some limitations. First, the cross-sectional design of the current study did not allow us to infer the cause-effect associations. For example, it is not clear whether mental health problems precede the adherence to smoking, or whether the smoking causes depression and anxiety. Second, the observed gender-specific association requires more research to determine the potential modifying effect of sex. It is not clear at this stage whether the different associations are true or attributable to methodological limitations. However, it is possible that some differences in lifestyle factors between men and women, such as smoking habits or physical activity, may explain the differences in risk between the sexes. Although the confounding effects of such variables have been considered in our multivariable fitted logistic model, the residual effects of such confounders or unknown or unmeasured confounders may influence the results. Finally, our study relied on the use of self-reported data.

The strengths of this study include the novelty of the topic in Iran and Middle Eastern countries as well as the use of validated questionnaires to evaluate mental health problems and physical activity. In addition, the large sample size of the study population with a wide variation in demographic variables may make our results generalizable to other populations.

\section{CONCLUSION}

In conclusion, this study provided new data in a rarely studied region and reinforced the available evidence regarding the relationship between lifestyle factors and two common mental health problems. Considering the adverse health outcomes associated with mental illness, as well as the large burden on individuals and society and the socioeconomic impact, there is a need to expand our knowledge in this context. We must develop new interventional strategies to reduce the incidence of psychiatric disorders and consequently their adverse health outcomes.

\section{CONFLICT OF INTEREST}

The authors have no conflicts of interest associated with the material presented in this paper.

\section{REFERENCES}

1. Kessler RC, Aguilar-Gaxiola S, Alonso J, Chatterji $\mathrm{S}$, Lee S, Ormel J, et al. The global burden of mental disorders: an update from the WHO World Mental Health (WMH) surveys. Epidemiol Psychiatr Sci. 2009;18(1):23-33.

2. Philipp J, Zeiler M, Waldherr K, Truttmann S, Dur W, Karwautz AFK, et al. Prevalence of emotional and behavioral problems and subthreshold psychiatric disorders in Austrian adolescents and the need for prevention. Soc Psychiatry Psychiatr Epidemiol. 2018.

3. Kessler RC, Berglund P, Demler O, Jin R, Merikangas $\mathrm{KR}$, Walters EE. Lifetime prevalence and age-of-onset distributions of DSM-IV disorders in the National Comorbidity Survey Replication. Arch Gen Psychiatry. 2005;62(6):593-602.

4. Wittchen H-U, Jacobi F, Rehm J, Gustavsson A, Svensson M, Jönsson B, et al. The size and burden of mental disorders and other disorders of the brain in Europe 2010. Eur Neuropsychopharmacol. 2011;21(9):655-79.

5. Mohammadi M-R, Davidian H, Noorbala AA, Malekafzali H, Naghavi HR, Pouretemad HR, et al. An epidemiological survey of psychiatric disorders in Iran. Clin Pract Epidemiol Ment Health. 2005;1(1):16.

6. Khazaie H, Najafi F, Hamzeh B, Chehri A, RahimiMovaghar A, Amin-Esmaeili M, et al. Cluster analysis of psychiatric profile, its correlates, and using mental health services among the young people aged 15-34: findings from the first phase of Iranian youth cohort in Ravansar. Soc Psychiatry Psychiatr Epidemiol. 2018.

7. Lokkerbol J, Adema D, de Graaf R, ten Have M, Cuijpers P, Beekman A, et al. Non-fatal burden of disease due to mental disorders in the Netherlands. Soc Psychiatry Psychiatr Epidemiol. 2013;48(10):1591-9. 
8. Green MJ, Benzeval M. The development of socioeconomic inequalities in anxiety and depression symptoms over the lifecourse. Soc Psychiatry Psychiatr Epidemiol 2013;48(12):1951-61.

9. Viana MC, Andrade LH. Lifetime prevalence, age and gender distribution and age-of-onset of psychiatric disorders in the São Paulo Metropolitan Area, Brazil: results from the São Paulo Megacity Mental Health Survey. Revista Brasileira de Psiquiatria. 2012;34(3):249-60.

10. Velten J, Lavallee KL, Scholten S, Meyer AH, Zhang X-C, Schneider S, et al. Lifestyle choices and mental health: a representative population survey. BMC Psychol. 2014;2(1):1.

11. Jonsdottir IH, Rödjer L, Hadzibajramovic E, Börjesson M, Ahlborg G. A prospective study of leisure-time physical activity and mental health in Swedish health care workers and social insurance officers. Prev Med. 2010;51(5):373-7.

12. Xu Q, Anderson D, Courtney M. A longitudinal study of the relationship between lifestyle and mental health among midlife and older women in Australia: findings from the Healthy Aging of Women Study. Health Care Women Int. 2010;31(12):1082-96.

13. Fogelholm M. Physical activity, fitness and fatness: relations to mortality, morbidity and disease risk factors. A systematic review. Obes Rev. 2010;11(3):202-21.

14. Schane RE, Ling PM, Glantz SA. Health effects of light and intermittent smoking. Circulation. 2010;121(13):1518-22.

15. Harriss D, Atkinson G, Batterham A, George K, Tim Cable N, Reilly $\mathrm{T}$, et al. Lifestyle factors and colorectal cancer risk (2): a systematic review and meta-analysis of associations with leisure-time physical activity. Colorectal Dis. 2009;11(7):689-701.

16. Scarborough P, Nnoaham KE, Clarke D, Capewell S, Rayner M. Modelling the impact of a healthy diet on cardiovascular disease and cancer mortality. J Epidemiol Community Health. 2012;66(5):420-6.

17. Rao S, Shah N, Jawed N, Inam S, Shafique K. Nutritional and lifestyle risk behaviors and their association with mental health and violence among Pakistani adolescents: results from the National Survey of 4583 individuals. BMC public health. 2015;15(1):1.

18. Yang H, Gao J, Wang T, Yang L, Liu Y, Shen Y, et al. Association between adverse mental health and an unhealthy lifestyle in rural-to-urban migrant workers in Shanghai. J Formos Med Assoc. 2017;116(2):90-8.

19. Piwoński J, Piwońska A, Sygnowska E. Do depressive symptoms adversely affect the lifestyle? Results of the WOBASZ study. Kardiol Pol. 2010;68(8):912-8.

20. Adibi P, Keshteli AH, Esmaillzadeh A, Afshar H, Roohafza $H$, Bagherian-Sararoudi R, et al. The study on the epidemiology of psychological, alimentary health and nutrition (SEPAHAN): overview of methodology. J Res Med Sci. 2012;17(2):291-7.

21. Promoting N. Creating Built or Natural Environments that Encourage and Support Physcial Activity: Scope. London: National Institute for Health and Clinical Excellence. 2006.

22. Montazeri A, Vahdaninia M, Ebrahimi M, Jarvandi S. The Hospital Anxiety and Depression Scale (HADS): translation and validation study of the Iranian version. Health Qual Life Outcomes. 2003;1(1):14.

23. Noorbala A, Yazdi SB, Yasamy M, Mohammad K. Mental health survey of the adult population in Iran. Br J Psychiatry. 2004;184(1):70-3.

24. Klose M, Jacobi F. Can gender differences in the prevalence of mental disorders be explained by sociodemographic factors? Arch Womens Ment Health. 2004;7(2):133-48.

25. Barcelos-Ferreira R, Pinto JA, Nakano EY, Steffens DC, Litvoc J, Bottino CM. Clinically significant depressive symptoms and associated factors in community elderly subjects from Sao Paulo, Brazil. Am J Geriatr Psychiatry. 2009;17(7):582-90.

26. van der Veen DC, Van Zelst W, Schoevers R, Comijs $\mathrm{H}$, Voshaar RO. Comorbid anxiety disorders in late-life depression: results of a cohort study. Int Psychogeriatr. 2015;27(07):1157-65.

27. Andrade L, Caraveo-Anduaga J, Berglund P, Bijl R, Kessler R, Demler O, et al. Cross-national comparisons of the prevalences and correlates of mental disorders. Bull World Health Organ. 2000;78(4):413-26.

28. Flint AJ, Peasley-Miklus C, Papademetriou E, Meyers BS, Mulsant BH, Rothschild AJ, et al. Effect of age on the frequency of anxiety disorders in major depression with psychotic features. The American journal of geriatric psychiatry : official journal of the American Association for Geriatric Psychiatry. 2010;18(5):404-12.

29. Afifi TO, Cox BJ, Enns MW. Mental health profiles among married, never-married, and separated/divorced mothers in a nationally representative sample. Soc Psychiatry Psychiatr Epidemiol. 2006;41(2):122-9.

30. Holt-Lunstad J, Birmingham W, Jones BQ. Is there something unique about marriage? The relative impact of marital status, relationship quality, and network social support on ambulatory blood pressure and mental health. Ann Behav Med. 2008;35(2):239-44.

31. Scott KM, Wells JE, Angermeyer M, Brugha TS, Bromet E, Demyttenaere K, et al. Gender and the relationship between marital status and first onset of mood, anxiety and substance use disorders. Psychological medicine. 2010;40(9):1495-505

32. Kelly SJ, Daniel M, Dal Grande E, Taylor A. Mental illhealth across the continuum of body mass index. BMC Public Health. 2011;11(1):765.

33. Onyike CU, Crum RM, Lee HB, Lyketsos CG, Eaton WW. Is obesity associated with major depression? Results from the Third National Health and Nutrition Examination Survey. Am J Epidemiol. 2003;158(12):1139-47.

34. Scott KM, Bruffaerts R, Simon GE, Alonso J, Angermeyer M, de Girolamo G, et al. Obesity and mental disorders in the general population: results from the world mental health surveys. Int J Obes. 2008;32(1):192-200.

35. Pine DS, Cohen P, Brook J, Coplan JD. Psychiatric symptoms in adolescence as predictors of obesity in early adulthood: a longitudinal study. Am J Public Health. 1997;87(8):1303-10. 
36. Robert E R, William J S, Stephane D, George A K. Are the fat more jolly? Ann Behav Med. 2002;24(3):169-80.

37. Richardson LP, Davis R, Poulton R, McCauley E, Moffitt TE, Caspi A, et al. A longitudinal evaluation of adolescent depression and adult obesity. Arch Pediatr Adolesc Med. 2003;157(8):739-45.

38. Blaine B. Does depression cause obesity? A meta-analysis of longitudinal studies of depression and weight control. Health Psychol. 2008;13(8):1190-7.

39. de Wit LM, Fokkema M, van Straten A, Lamers F, Cuijpers P, Penninx BW. Depressive and anxiety disorders and the association with obesity, physical, and social activities. Depression and anxiety. 2010;27(11):1057-65.

40. Anderson E, Shivakumar G. Effects of exercise and physical activity on anxiety. Frontiers in psychiatry. 2013;4:27.
41. Jacka FN. Lifestyle factors in preventing mental health disorders: an interview with Felice Jacka. BMC Med. 2015;13(1):264.

42. Herring MP, O'connor PJ, Dishman RK. The effect of exercise training on anxiety symptoms among patients: a systematic review. Arch Intern Med. 2010;170(4):321-31.

43. Fluharty M, Taylor AE, Grabski M, Munafò MR. The Association of Cigarette Smoking With Depression and Anxiety: A Systematic Review. Nicotine Tob Res. 2016;19(1): 3-13.

44. Chaiton MO, Cohen JE, O'Loughlin J, Rehm J. A systematic review of longitudinal studies on the association between depression and smoking in adolescents. BMC Public Health. 2009;9(1):356.

45. Boden JM, Fergusson DM, Horwood LJ. Cigarette smoking and depression: tests of causal linkages using a longitudinal birth cohort. Br J Psychiatry. 2010;196(6):440-6. 